\title{
Meaning of microalbuminuria during the atopic dermatitis of the child
}

\author{
Ida Aurélie Lenga Loumingou', Richard Loumingou² \\ ${ }^{1}$ Department of Dermatology, University of Brazzaville Medical Center, Brazzaville, Republic of the Congo, ${ }^{2}$ Department of \\ Nephrology, University of Brazzaville Medical Center, Brazzaville, Republic of the Congo
}

Corresponding author: Dr. Ida Aurélie Lenga Loumingou, E-mail: idalengaloumingou@gmail.com

\begin{abstract}
Objectives: Advocate early diagnosis of vascular diseases in children with atopic dermatitis. Determine children at vascular risk during atopic dermatitis. Method: The study is transversal and analytical; performed in the University of Brazzaville Medical Center in 18 months. It focuses on children from 0 to 15 years old with atopic dermatitis. The anthropometric, clinical, and antecedent data are collected on cards as well as the balance necessarily including: fasting blood glucose, serum immunoglobulin E (IGE) and microalbuminuria. Results: 80 patients were selected, 47 girls and 33 boys. The mean age was 8.9 years $\mathrm{SD} \pm 4.646$. Obesity is found in $21.25 \%$ of cases. $82,5 \%$ of children had hypertensive parents or diabetics in the first degree. Microalbuminuria was positive in $53.75 \%$ of cases. It was independent of age and sex and more common in children with hyper IgE. Conclusion: The study reports arguments for a vascular predisposition and show the interest of achieving microalbuminuria in atopic dermatitis.
\end{abstract}

Key words: Atopic dermatitis; Arterial hypertension; Diabetes; Microalbuminuria; Child

\section{INTRODUCTION}

Atopic dermatitis (AD) is an inflammatory, pruritic and chronic condition of complex etiopathogenesis with implications for hereditary factors and environmental antigens [1]. Atopic dermatitis can be considered as a systemic disease [2], its clinical diagnosis is done by the criteria of the United Kingdom Working Party.

DA is a model of polygenic inheritance that is accompanied by stimulations of secretion of polypeptide substances and chemical mediators with vasoactive activity [1]. Some metabolic manifestations such as obesity and some idiopathic nephrotic syndromes are described in $\mathrm{AD}[3,4]$. The occurrence of arterial hypertension during atopic dermatitis has been suggested [5].

The authors conducted a hospital study to look for a link between $\mathrm{AD}$ and common vascular pathologies such as diabetes, high blood pressure and obesity. The interest of this study is to advocate early detection and prevention of vascular diseases in children with AD.

\section{PATIENTS AND METHOD}

It is a transversal and analytical study, carried out in University of Brazzaville Medical Center in consultation from January 2015 to July 2016. The study is made by a Dermatologist and a nephrologist hospital-university.

Inclusion criteria were: patients aged $0-15$ years with AD. Exclusion criteria were: urinary tract infection or other active infection, ongoing or long-term steroid therapy.

The clinical and laboratory parameters studied were: body mass index, personal and family history of diabetes, high blood pressure, asthma, ambulatory blood pressure measurement with a suitable cuff, fasting blood glucose, blood count, $\mathrm{C}$ reactive protein, cytobacteriological examination of urine, ADDIS count, serum immunoglobulin E (IGE), microalbuminuria.

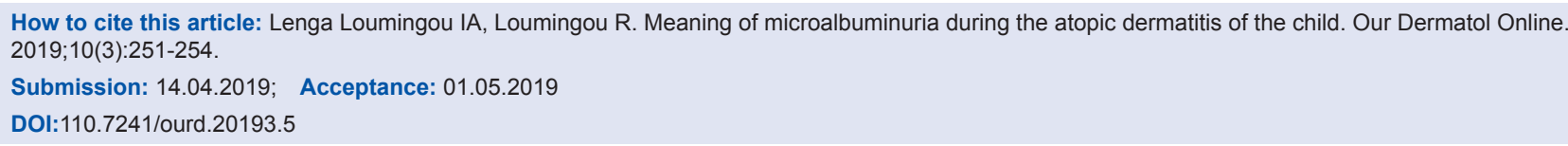


Microalbuminuria was performed on urination, it was considered positive when it was greater than $20 \mathrm{ml} / \mathrm{g}$.

The diagnosis of $\mathrm{AD}$ was made thanks to the criteria of the United Kingdom Working Party. The severity of the AD was defined by the SCORAD index.

The information was recorded on cards. Data analysis was done by SPSS for calculating averages, standard deviations and correlations.

\section{RESULTS}

\section{Epidemiological aspects}

374 children were received during the study period among them, 87 had an AD (23.6\%) and 80 met the criteria of the study. There were 33 boys and 47 girls. The $\mathrm{M} / \mathrm{F}$ ratio was 0.7 . The average age was 8.9 years $\mathrm{SD} \pm 4.646$ years. The average age of girls was $10.19 \pm 4.08$ and $7.24 \pm 4.89$ for boys $(\mathrm{P}=0.099)$.

\section{Clinical aspects}

There was no diabetes or ongoing hypertension in the patients.13 children were asthmatic (16.25\%), 17 obese children (21.25\%), 66 children had parents with diabetes or hypertension (82.5\%); distributed as follows: high blood pressure $(\mathrm{n}=46)$, hypertension and diabetes $(\mathrm{n}=12)$, diabetes $(\mathrm{n}=8)$.

\section{Biological aspects}

Microalbuminuria was positive in 43 cases (53.75\%). Mean microalbuminuria was $24.20 \pm 21.40$. This average was evaluated at $27.4 \pm 28.57$ for boys and $21.93 \pm 14.35$ for girls $(\mathrm{P}=0.016) .80 \%$ of children with microalbuminuria had hypertensive or diabetic parents. IgE was elevated in $45 \%$ of patients. The average $\operatorname{IgE}$ was $339.2 \pm 371.5$.

\section{Correlation between microalbuminuria and the different variables studied}

Positive microalbuminuria was found in $47.3 \%$ of children in the 0 to 4 age group, $50 \%$ had positive microalbuminuria in the age group of 5 to 9 years, and $60 \%$ between 10 and 15 years old. The Pearson correlation rate is 0.022 , bilateral significance 0.845 (Table 1). The averages of microalbuminuria with respect to age are shown in Fig. 1.

Positive microalbuminuria was found in $45 \%$ of children who have hyper IgE. The Pearson correlation was 0.212 ;
Table 1: Corrections between microalbuminuria and different variables

\begin{tabular}{lccc}
\hline & Age & Microalbuminy & IGE \\
\hline Age & & & \\
$\quad$ Correlation of pearson & 1 & 0.022 & 0.208 \\
Sig. (bilateral) & & 0.845 & 0.063 \\
N & 80 & 80 & 80 \\
Microalbuminy & & & \\
$\quad$ Correlation of pearson & 0.022 & 1 & 0.212 \\
Sig. (bilateral) & 0.845 & & 0.059 \\
N & 80 & 80 & 80 \\
IGE & & & \\
Correlation of pearson & 0.208 & 0.212 & 1 \\
Sig. (bilateral) & 0.063 & 0.059 & \\
N & 80 & 80 & 80 \\
\hline
\end{tabular}

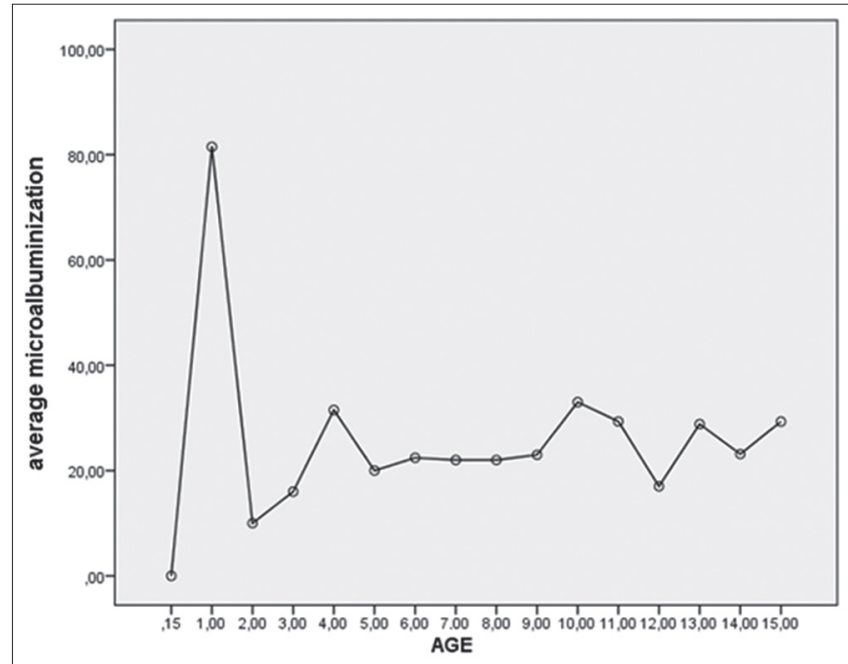

Figure 1: Microalbuminurie and age.

Bilateral significance 0.059. The microalbuminuria averages by age group are shown in Fig. 1.There were 13 asthmatic patients among whom 5 (38.4\%) had microalbuminuria. Severe AD exist in $23.75 \%$ cases, $73.6 \%$ of whom had hyper $\operatorname{IgE}$ and positive microalbuminuria.

\section{DISCUSSION}

Atopic dermatitis is an inflammatory, pruriginous and spongiotic disease [6]. It is considered a systemic disease [2]. prevalence of AD is high but varies by study [7-9]. The classic feminine predominance is found in our study [10]. The penetrance of $\mathrm{AD}$ is variable, comorbidity is common [11] other manifestations of atopy are often associated. In the study, $16.25 \%$ of children were asthmatic, $24.7 \%$ had AD strict.

The physiopathology of AD is complex [1]; it is accompanied by stimulations, secretions of chemical 
mediators and a high cellular activity [12]. These mechanisms are arguments for an alteration of the endothelial tissue. There is a relationship between inflammatory mediators and vascular and metabolic risk factors: interleukin 6 induces insulin resistance [13], cytokines (TNF, IL6, interferon gamma) have a pro-inflammatory role [14], T h 1, T $\mathrm{h} 2$ regulatory $\mathrm{T}$ lymphocytes, whose activity is crucial in $\mathrm{AD}$, induce atherosclerosis [15], podocyte damage is found in the idiopathic nephrotic syndromes of atopic subjects [16].

The arguments for a vascular predisposition in our study are: $82.5 \%$ of first degree parents were diabetic and or hypertensive, the positivity of microalbuminuria in $53.75 \%$ of children.

The association of AD with obesity, diabetes and arterial hypertension is gaining acceptance $[17,18]$. The link between idiopathic nephrotic syndrome and atopic dermatitis has been suggested $[4,16]$. In our study $26.25 \%$ of children were obese. No child was hypertensive or diabetic. For Zhang [19], obesity is controversial in AD but is frequently reported in studies such as Kusunoki [3] and Lim [20]. The small sample in the study did not allow us to associate obesity with AD. Microalbuminuria reflects either a rise in capillary pressure or an alteration of the triple glomerular barrier or a generalized endothelial dysfunction it is a risk factor cardiovascular whose interest is established in the management of diabetes and high blood pressure [21]. Positive microalbuminuria appeared to exist independently of age, more than half of the patients had positive microalbuminuria. We did not find an explanation for the peak before the age of two. The positivity of microalbuminuria appeared to be related to the elevation of immunoglobulin $\mathrm{E}$ and the severity of AD.

\section{CONCLUSION}

The existence of pathological microalbuminuria in children with $\mathrm{AD}$ seems to be relevant. It seems important to systematically look for personal and familial vascular risk factors in children with AD, to ensure optimal prevention of common vascular diseases.

\section{Statement of Human and Animal Rights}

All procedures followed were in accordance with the ethical standards of the responsible committee on human experimentation (institutional and national) and with the Helsinki Declaration of 1975, as revised in 2008 .

\section{Statement of Informed Consent}

Informed consent was obtained from all patients for being included in the study.

\section{REFERENCES}

1. Barbarot S. Physiopathologie de la dermatite atopique et perspectives thérapeutiques systémiques. Réal Thér DermatoVénérol. 2016;256:1.

2. Darlenski R, Kazandjeva J, Hristakieva E, Fluhr JW. Atopic dermatitis as a systemic disease. Clin Dermatol. 2014;32:409-13.

3. Kusunoki T. Obesity and atopic dermatitis, allergic rhinitis. Arerugi. 2017;66:984-9.

4. Audard V, Lang P, Sahali DIL. Pathogénie du syndrome néphrotique à lésions glomérulaires minimes. Med Sci (Paris). 2008;24:853-8.

5. Silverberg JL, Becker L, Kwasny M, Menter A, Kordoro KM, Paller AS. Central obesity and high blood pressure in pediatric patient with atopic dermatitis. J Am Acad Dermatol. 2015;151:144-52.

6. Misery L. Atopic dermatidis: new trends and persoectives. Clin Rev Allerg Immunol. 2011;41:296-7.

7. Baghoud S. Prévalence et profil clinique de la Dermatite atopique en Algérie. Ann Dermatol Vénérol. 2012;9:13140.

8. Kay J, Gawkrodger DJ, Mortimer MJ, Jaron AG. The prevalence of childhood atopic eczema in a general population. J Am Acad Dermatol. 1994;30:35-9.

9. Xu F, Yan S, Li F, Cai M, Chai W, Wu M, et al. Prevalence of childhood atopic dermatitis an urban and rural community-based study in Shanghai, China. PLOS One. 2012;7:e 36174.

10. Charpin D, Vervloet D. Présentation générale de l'étude ISAAC. Rev Franç d'Allergol d'Immunol Clin. 1998;38:375-382.

11. Davis D. Practice gaps. Pediatric atopic dermatitis and associated morbidities. J Am Acad Dermatol. 2015;151:152-3.

12. Gittler JK, Shemer A, Suarez Farinas M, Fuentes-Duculan J, Gulewicz KJ, Wang CQ, et al. Progressive activation of Th2 Th22 cytokines and selective epidermal proteins characterizes acute and chronic atopic dermatitis. J Allergy Clin Immunol. 2012;130:1344-54.

13. Bastard J P, Feve B. Insulino résistance et Diabète: Quel rôle jouent les interleukines. STV. 2009;21:307-14.

14. Ait oufella H, Tedgui A, Mallat Z. L'athérosclérose: une maladie inflammatoire. STV. 2008;20:25-33.

15. Robertson AK, Hansson GK. T cells in artherogenesis: for better or worse. Aterioscler Thromb Vasc Biol. 2006;26:2421-32.

16. Wei CC, Lin CL, Shen TC, Sung FC. Occurrence of common allergic diseases in children with idiopathic nephrotic syndrome. J Epidemiol. 2015;25:370-7.

17. Thyssen JP, Halling-Overgaard AS, Andersen YMF, Gislason G, Skov L, Egerberg A. The association between cardiovascular disease and type 2 diabetes in adults with atopic dermatitis: a systematic review and meta-analysis. J Dermatol. 2018;178:879-88.

18. Andersen YMF, Egeberg A, Hamann CR, Skov L, Gislason GH, Skaaby T, Linneberg A, Thyssen JP. Poor agreement in questionnaire-based diagnostic criteria for adult atopic dermatitis is a challenge when examining cardiovascular comorbidity. Allergy. 2018;73:923-31.

19. Zhang A, Silverberg JI. Association of atopic dermatitis with bering overweight and obese: a systematic review and meta analysis. J Am Acad Dermatol. 2015;72:606-16. 
www.odermatol.com

20. Lim MS, Lee CH, Sim S, Hong SK, Choi HG. Physical Activity, Sedentary Habits, Sleep, and Obesity are Associated with Asthma, Allergic Rhinitis, and Atopic Dermatitis in Korean Adolescents. Yonsei Med J. 201758:1040-6.

21. Sizinger $\mathrm{H}$, Kritz H. La microalbuminurie est elle un facteur de risque en pathologie vasculaire. Sang Thromb Vaiss. 1995;7:613-8.
Copyright by Ida Aurélie Lenga Loumingou, et al. This is an open-access article distributed under the terms of the Creative Commons Attribution License, which permits unrestricted use, distribution, and reproduction in any medium, provided the original author and source are credited.

Source of Support: Nil, Conflict of Interest: None declared. 